\title{
Maxillary Canine with two roots and two canals: A case report
}

\author{
Canino Superior com duas raízes e dois canais: Um relato de caso \\ Canino Maxilar con dos raíces y dos conductos: Reporte de un caso
}

Received: 02/02/2021 | Reviewed: 02/07/2021 | Accept: 02/12/2021 | Published: 02/19/2021

Fausto Rodrigo Victorino

ORCID: https://orcid.org/0000-0002-4603-5829

University Center of Maringá, Brasil

E-mail: frvictorino2014@gmail.com

Isabela Silva Rocha

ORCID: https://orcid.org/0000-0002-5746-4127

State University of Maringá, Brasil

E-mail: rochaisabelaa@gmail.com

Rafael de Oliveira Lazarin

ORCID: https://orcid.org/0000-0002-2104-3945 Private Clinic, Brasil

E-mail: lazarinrafael@gmail.com

Marcelo Augusto Seron

ORCID: https://orcid.org/0000-0001-7160-6550

São Paulo State University, Brazil

E-mail: marceloaseron@gmail.com

Gustavo Sivieri-Araujo

ORCID: https://orcid.org/0000-0002-8402-7408

São Paulo State University, Brazil

E-mail: gustavo.sivieri@unesp.br

Ricardo Sérgio Almeida

ORCID: https://orcid.org/0000-0002-1427-936X

Londrina State University, Brazil

E-mail: rikodonto@gmail.com

\begin{abstract}
Introduction: Knowledge of the anatomy and root canal system is of fundamental importance for a successful endodontic treatment. Maxillary canines unusually possess two root canals. Aim: The present study aims to present a maxillary canine with two roots and two canals through a clinical case. Case report: A male patient was referred for the treatment of a root perforation of the tooth 23. Clinical examination revealed the presence of vestibular fistula and mild pain with vertical and horizontal percussion. Through a tomographic examination, the presence of two roots and two root canals was observed in addition to a radiolucent lesion at the middle third of the roots but without perforation in the middle third. Coronary opening and the localization of the vestibular and palatal canals were performed. The root canal length was performed with Romi Apex A-15® foraminal locator and instrumentation was conducted by using Protaper Next ${ }^{\circledR}$ system. Due to the presence of fistula, calcium hydroxide manipulated with propylene glycol was used as intracanal medication for 30 days. After this period, the root canals were filled with gutta-percha and AH Plus® cement and a new tomographic examination was undertaken, which confirmed the complete filling of the root canals and the absence of root perforation. Conclusion: Given the above, endodontic professionals shall be aware of possible anatomical variations and make use of auxiliary resources when appropriate, such as cone beam computed tomography (CBCT), to ensure correct diagnosis and, consequently, a successful root canal treatment.
\end{abstract}

Keywords: Anatomy; Canine teeth; Cone-beam computed tomography; Endodontics.

\section{Resumo}

Introdução: $\mathrm{O}$ conhecimento da anatomia e do sistema de canais radiculares é de fundamental importância para o sucesso do tratamento endodôntico. Os caninos superiores raramente possuem dois canais radiculares. Objetivo: O presente estudo tem como objetivo apresentar um canino superior com duas raízes e dois canais por meio de um caso clínico. Paciente do sexo masculino foi encaminhado para tratamento da perfuração radicular do dente 23 . O exame clínico revelou presença de fístula vestibular e dor leve à percussão vertical e horizontal. Ao exame tomográfico, observou-se a presença de duas raízes e dois canais radiculares, além de lesão radiolúcida no terço médio das raízes, mas sem perfuração no terço médio. Foram realizadas a abertura coronária e localização dos canais vestibular e palatino. A odontometria eletrônica foi realizada com o localizador foraminal Romi Apex A-15® e a instrumentação com o sistema Protaper Next®. Devido à presença de fístula, hidróxido de cálcio manipulado com propilenoglicol foi utilizado como medicação intracanal por 30 dias. Após esse período, os canais foram preenchidos com guta-percha e cimento AH Plus ${ }^{\circledR}$ e um novo exame tomográfico foi solicitado, o qual confirmou o preenchimento completo dos 
canais radiculares e a ausência de perfuração radicular. Conclusão: Diante do exposto, o profissional deve estar sempre atento às possíveis alterações anatômicas e, frequentemente, utilizar recursos auxiliares, como a tomografia computadorizada do feixe cônico, garantindo o diagnóstico correto e, consequentemente, o sucesso da terapia endodôntica.

Palavras-chave: Anatomia; Dente canino; Tomografia computadorizada de feixe cônico; Endodontia.

\section{Resumen}

Introducción: El conocimiento de la anatomía y el sistema de conductos radiculares es de fundamental importancia para el éxito del tratamiento de endodoncia. Los caninos maxilares tienen inusualmente dos conductos radiculares. Objetivo: El presente estudio posee como objetivo presentar un canino maxilar con dos raíces y dos canales a través de un caso clínico. Reporte de un caso: Un paciente masculino fue remitido para el tratamiento de una perforación radicular del diente 23. El examen clínico reveló la presencia de fístula vestibular y dolor leve con percusión vertical y horizontal. Al examen tomográfico se observó la presencia de dos raíces y dos conductos radiculares, además de una lesión radiolúcida en el tercio medio de las raíces, pero sin perforación en el tercio medio. Se realizó apertura coronaria y localización de los conductos vestibular y palatino. La odontometría electrónica se realizó con el localizador foraminal Romi Apex A-15® y la instrumentación se realizó con el sistema Protaper Next®. Debido a la presencia de fístula, se utilizó hidróxido de calcio manipulado con propilenglicol como medicación intracanal durante 30 días. Transcurrido este período se rellenaron los conductos radiculares con gutapercha y cemento AH Plus ${ }^{\circledR}$ y se solicitó un nuevo examen tomográfico, que confirmó el llenado completo de los conductos radiculares y la ausencia de perforación radicular. Conclusión: Dado lo anterior, el profesional debe estar siempre atento a los posibles cambios anatómicos y, a menudo, al uso de recursos auxiliares, como la tomografía computarizada dental de haz cónico, asegurando un diagnóstico correcto y, en consecuencia, una terapia endodóntica exitosa.

Palabras clave: Anatomía; Diente canino; Tomografía computarizada de haz cónico; Endodoncia.

\section{Introduction}

The success of endodontic treatment depends primarily on the maximum disinfection of the root canal system through mechanical chemical preparation and the use of irrigating solutions with antimicrobial activity (Hasna et al, 2020a). Cases of failure have been reported due to the persistence of microorganisms within the root canals, such as Enterococcus faecalis and Candida albicans (Hasna et al, 2020a and 2020b). In such cases, new auxiliary therapeutic proposals have been suggested and explored (Hasna \& Carvalho, 2019; Hasna et al 2020b). Conversely, the anatomical complexity of the root canals can also be a key factor for the failure of the endodontic treatment, since it hinders the mechanical action of endodontic instruments (Has na et al 2019b).

The root canal morphology and its variants are of extreme importance for the success of the endodontic treatment. The presence of undetected structural abnormalities can lead to failures in the localization, instrumentation, and obturation of the root canals (Barkhordar \& Nguyen, 1985; Orguneser \& Kartal, 1998; Alapati et al, 2006; Bolla \& Kavuri, 2011; Lamba, 2012; Shrivastava et al, 2013; Kavitha et al 2014; Roy et al, 2018; Muppalla et al, 2015; Mohammed et al, 2015).

Maxillary canines are usually uniradicular teeth with a single present canal. Therefore, the presence of two root canals in one canine is considered a rare condition, as reported by some authors (Alapati et al 2006; Bolla \& Kavuri, 2011; Lamba, 2012; Kavitha et al 2014; Muppalla et al, 2015; Mohammed et al, 2015, Plascencia et al, 2017). Although proven to be an extremely rare anomaly in dental morphology, canines containing two roots and presenting two root canals must be correctly and safely diagnosed for an effective endodontic treatment.

The complementary imaging examinations for confirmation of dental morphology is of crucial importance. Radiographs at different angulations, therefore, help in the correct diagnosis of these anatomical variations (Barkhordar \& Nguyen, 1985). However, this type of examination normally presents some limitations and, thus, does not correctly contribute to the achievement and success of the root canal treatment. A two-dimensional image of three-dimensional structures becomes a challenge in a correct interpretation of dental and bone structures. Hence, more accurate imaging exams, such as the conebeam computed tomography (CBCT), are required to overcome the diagnostic challenge of a canine with two roots (Scarparo $\&$ Neuvald, 2006). Consequently, CBCT has become an important tool for endodontists. It allows the visualization of three- 
dimensional anatomical structures with minimal image distortion, which contributes to a more credible diagnosis (Desai et al, 2015; Gopalakrishnan et al, 2017).

In this context, the present study aims to present the anatomical variation of a superior canine with two roots and two root canals and its successful treatment. For that, a clinical case together with tomographic images were used.

\section{Methodology}

This is an observational and descriptive study of a case report. The study respected the ethical principles of research in human beings, which was submitted and approved by the Ethics Committee (Protocol: \#40816820.0.0000.5539).

\section{Case Report}

A 17-year-old male patient was referred for the treatment of a root perforation of the tooth 23. Clinical examination revealed the presence of vestibular fistula and mild pain with vertical and horizontal percussion. The presence of two roots and two root canals, as well as a radiolucent lesion at the middle third of the roots, and an indication of perforation in the middle third were observed at tomographic examination (Figures 1 and 2).

Figure 1 - Initial sagittal cone beam computed tomography of the tooth 23.

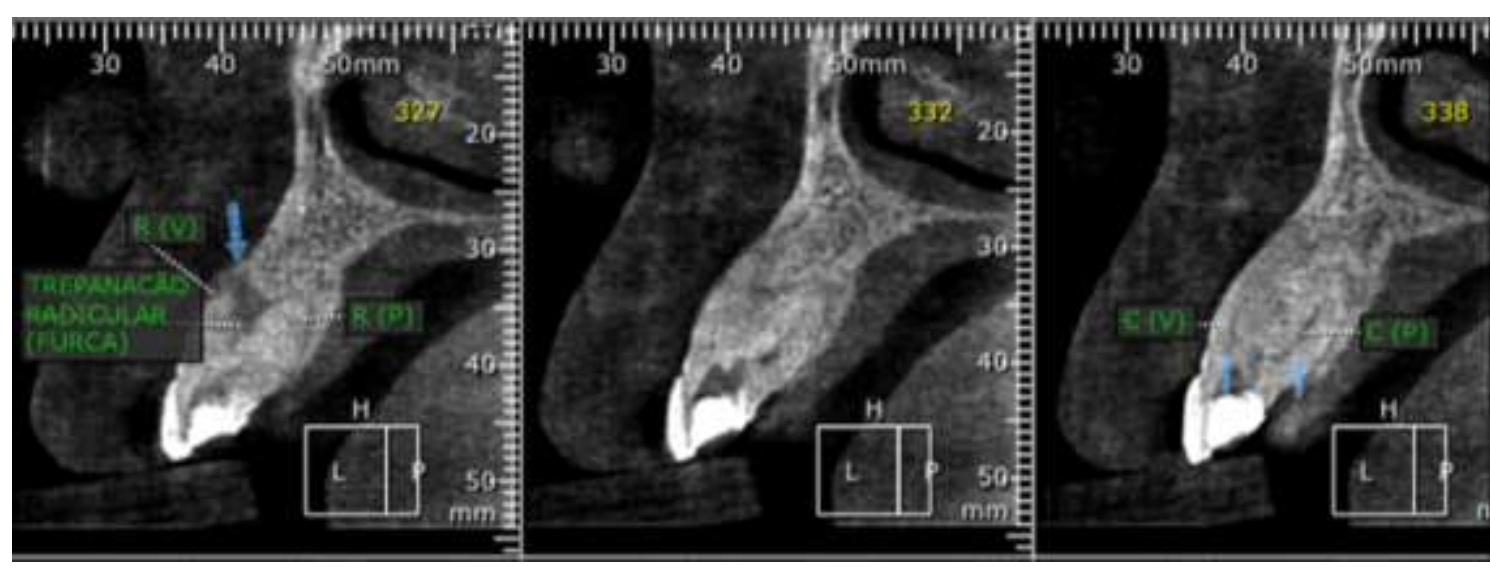

Source: Authors.

Figure 2 - Initial axial cone beam computed tomography of the tooth 23.

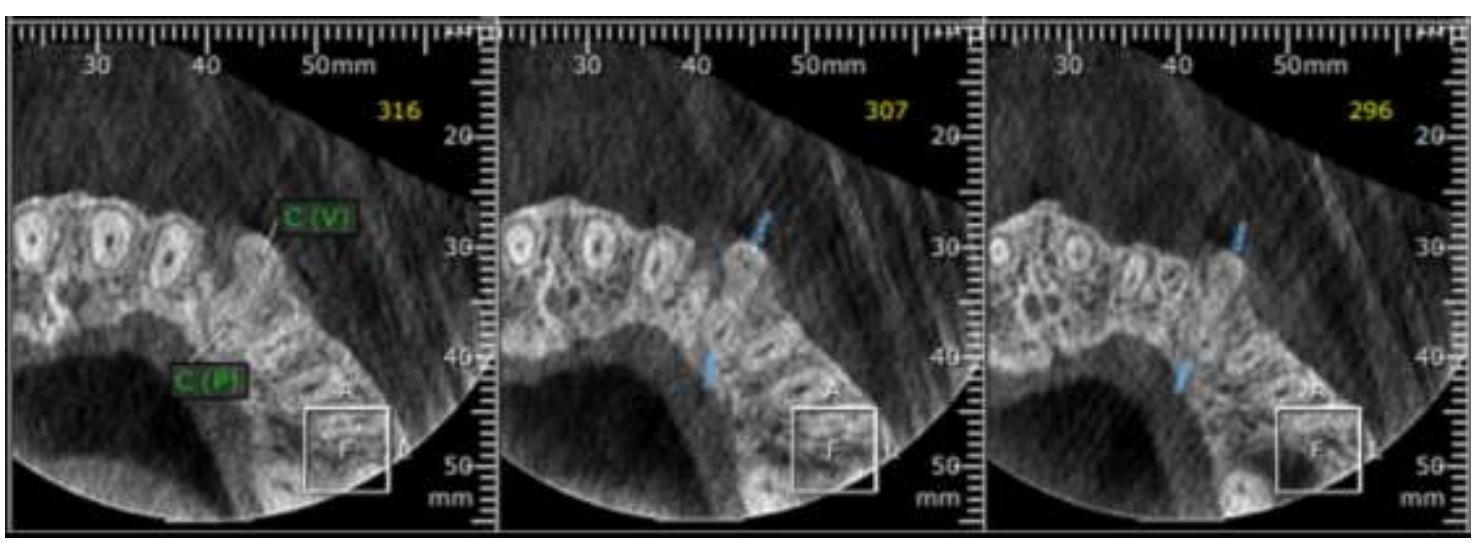

Source: Authors.

Coronary opening and the localization of the vestibular and palatal canal were performed using the E6D (pear diamond) ultrasonic insert (Helse Ultrasonic, Santa Rosa de Viterbo, São Paulo, Brazil) in 50\% power, coupled to an ultrasonic 
unit CVDent1000 (CVDentus, São José dos Campos, São Paulo, Brazil) due to calcification of the pulp chamber. Sodium hypochlorite 2,5\% (Asfer, São Caetano do Sul, São Paulo, Brazil) was used as an auxiliary irrigating solution to the chemicalmechanical preparation, and EDTA 17\% was administered (Biodinâmica, Ibiporã, Paraná, Brazil) to remove the smear layer. The root canal length was performed with Romi Apex A-15® (Romidan Ltd, Kiryat Ono, Israel). The tip of the maxillary canine was a reference to determine the length of the vestibular and palatal canal, which measured $25 \mathrm{~mm}$. The instrumentation was performed with X1 (17.04), X2 (25.06), and X3 (30.07) Protaper Next® system (Dentsply Maillefer, Ballaigues, Switzerland). Due to the presence of pulp necrosis and fistula, calcium hydroxide (Biodinâmica, Ibiporã, Paraná, Brazil) was manipulated with propylene glycol-USP (Quimidrol, Curitiba, Paraná, Brazil) and inserted into the canals with size 35 Lentulo spiral (Dentsply Maillefer, Ballaigues, Switzerland), was used as intracanal medication for 30 days.

After this period, the intracanal medication was completely removed and the root canal system was filled with the AH Plus ${ }^{\circledR}$ root canal sealer (Dentsply DeTrey GmbH, Konstanz, Germany) together with Gutta-Percha 30.07 Tanari (Tanariman Industrial LTDA, Manacapuru, Amazonas, Brazil). For that, the continuous condensation wave technique was used with Termo Pack II (Easy Equipamentos Odontológicos, Belo Horizonte, Minas Gerais, Brazil). The final periapical radiograph confirmed the complete filling of the root canals (Figure 3). After 15 days, a new CBCT was obtained, reaffirming the absence of root perforation and the complete filling of the three-dimensional root canals (Figures 4 and 5). Upon clinical and radiographic examination after 17 months (Figure 6), the tooth was asymptomatic and showed signs of normality.

Figure 3 - Root canal obturation of the tooth 23.

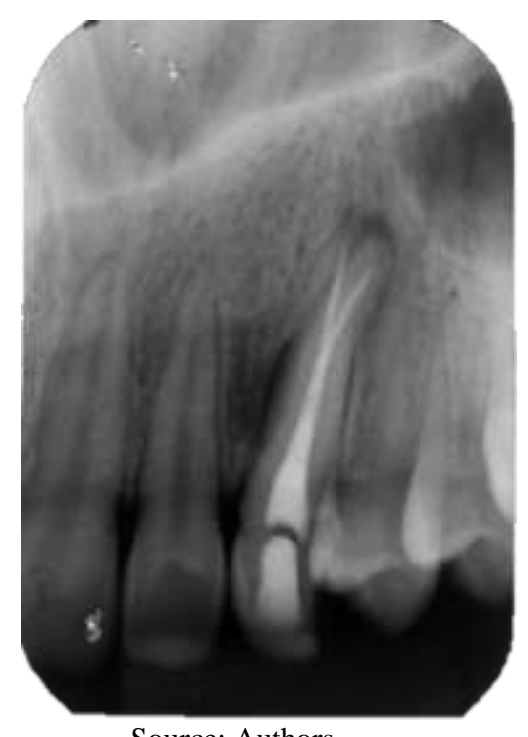

Source: Authors. 
Research, Society and Development, v. 10, n. 2, e36410212599, 2021

(CC BY 4.0) | ISSN 2525-3409 | DOI: http://dx.doi.org/10.33448/rsd-v10i2.12599

Figure 4 - Post-operative with 15 days. Final cone beam computed tomography of the tooth 23. A: Sagittal; B e C: Coronal.

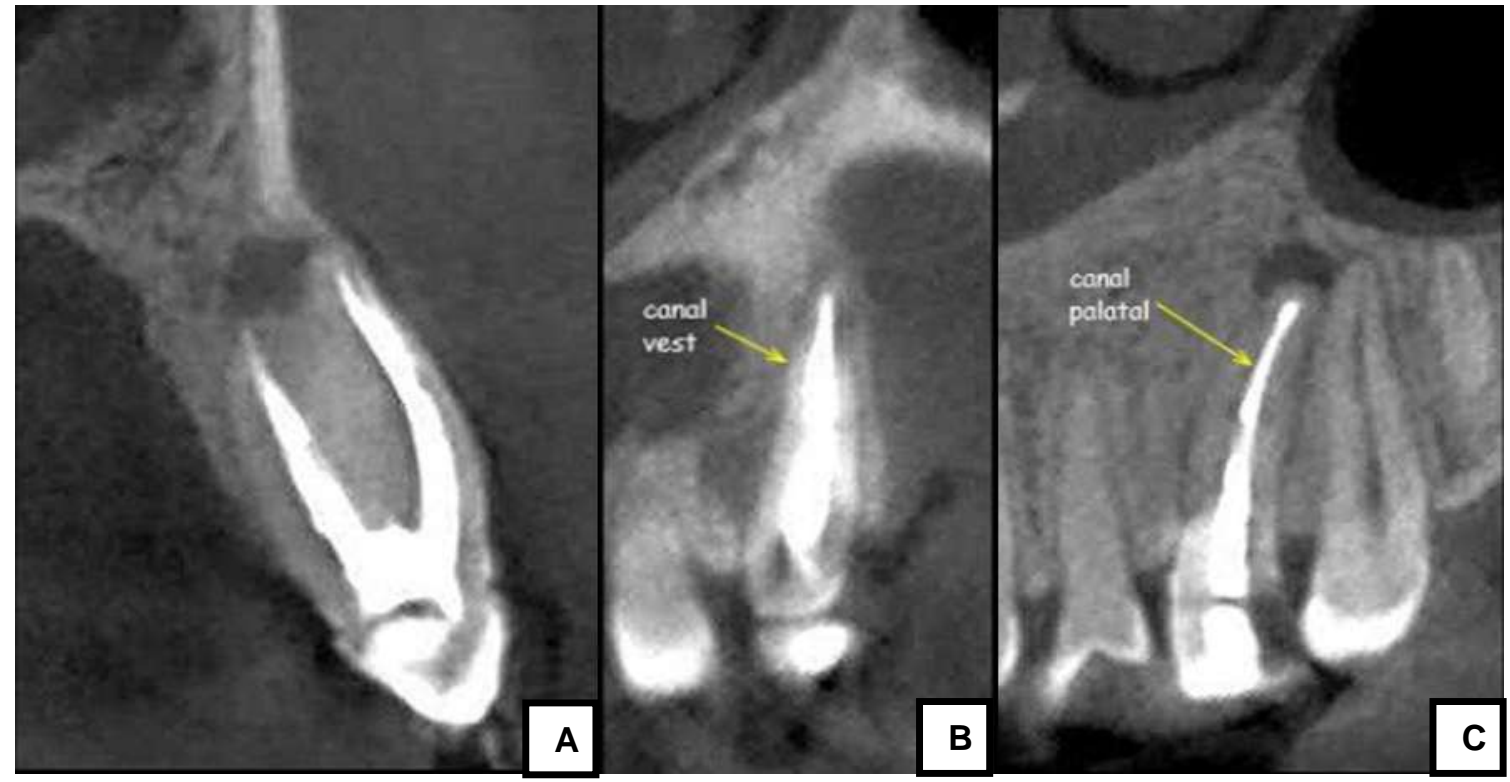

Source: Authors.

Figure 5 - Post-operative with 15 days. Final axial cone beam computed tomography of the tooth 23. A: Cervical; B: Middle; C: Apical.

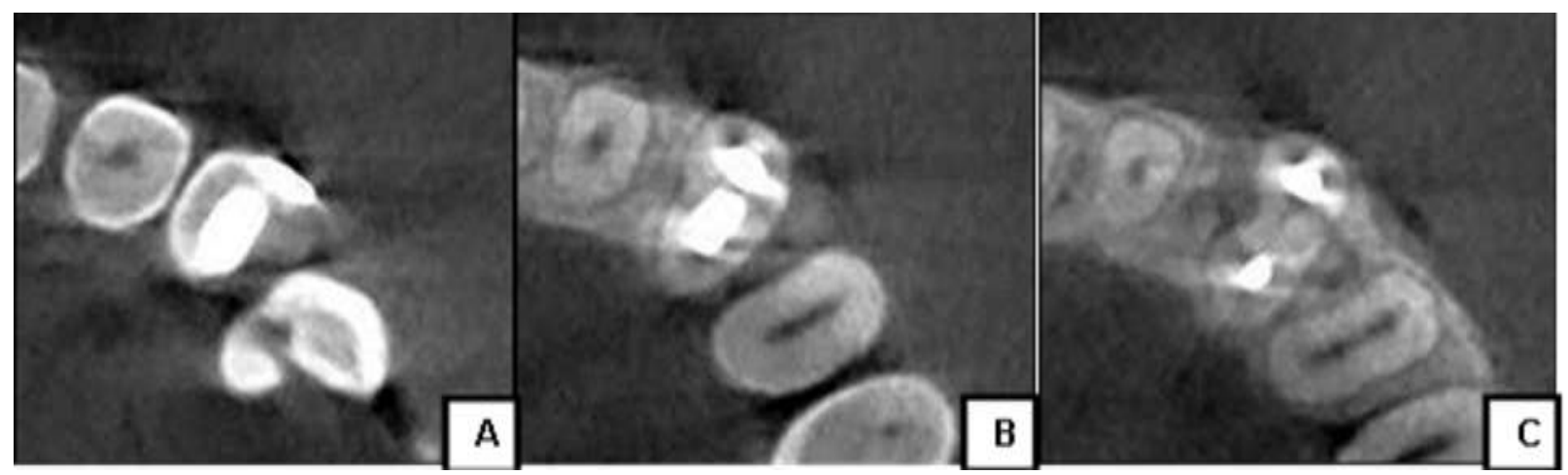

Source: Authors. 
Figure 6 - Periapical radiography post-operative with control after 17 months.

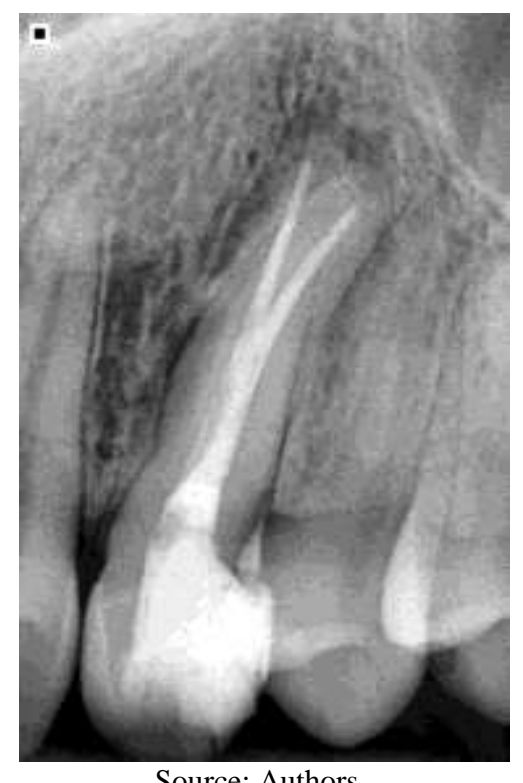

\section{Discussion}

Canines teeth with two roots and/or two root canals are considered to be uncommon (Alapati et al, 2006; Bolla \& Kavuri, 2011; Lamba, 2012; Muppalla et al, 2015; Mohammed et al, 2015; Plascencia et al, 2017). Perceiving the diversity of root canal systems, Vertucci (1984) conducted a study in which root canals were classified into eight types. After analysing 100 maxillary canines, the author concluded that $90 \%$ of them were type I, meaning 'a single root canal extending from the pulp chamber to the apex'. These results confirm with the study carried out by Plascencia et al. (2017). However, results from current literature have demonstrated a majority of upper canines of type II (Alapati et al, 2006; Bolla \& Kavuri, 2011; Lamba, 2012; Kavitha et al, 2014; Muppalla et al, 2015, Mohammed et al, 2015), whose anatomy consists of two separate canals leaving the pulp chamber and merging in the apical third to form a single canal. In this study, the dental element was classified as type IV, which consists of a tooth with two separate and distinct channels that leave the pulp chamber to the apex. Such anatomy further emphasizes its rarity, a fact endorsed by the work of Shin et al. (2011).

Studying these variations in the dental anatomy represents a great difficulty in diagnosis. Failing to locate root canals is considered one of the most common failures in endodontic treatment (Alapati et al, 2006; Bolla \& Kavuri, 2011; Shrivastava et al, 2013; Mohammed et al, 2015). Therefore, it is vital to know the internal dental anatomy in order to identify the correct number of root canals. For that, understanding and the use of appropriate instruments are essential (Bolla \& Kavuri, 2011; Shrivastava et al, 2013).

The initial radiographic acquisition in different angulations (Victorino et al, 2009) and its detailed analysis are of great value to the professional (Alapati et al, 2006; Muppalla et al, 2015). The performance of broader access openings and the use of adequate lighting and image enhancement, if possible, are also important tools for the endodontic treatment (Shrivastava et al, 2013). Likewise, the careful clinical endodontic exploration (Bolla \& Kavuri, 2011; Mohammed et al, 2015), and the use of an electronic apical locator (Lamba, 2012).

The radiographic examination is the most employed tool to aid root canal treatment. Nevertheless, the use of such apparatus can be inadequate in some cases, since its utilization presents some limitations, such as the two-dimensional reproduction of a three-dimensional element (Plascencia et al, 2017; Gopalakrishnan et al, 2017). As a result, interpretation may be impaired, especially when anatomical variations are present, causing diagnostic errors by the clinician and treatment 
failure (Ee et al, 2014).

Hence, CBCT represents a more accurate diagnostic method for dental morphological analysis, (Mohammed et al, 2015; Gopalakrishnan et al, 2017; Oliveira et al, 2021) since it provides a three-dimensional image obtained with a low radiation dose. As such, CBCT allows treatment's predictability (Ee et al, 2014) with almost no discomfort for patients (Mohammed et al, 2015; Gopalakrishnan et al, 2017).

In endodontics, CBCT should be requested in a particular case, in which the benefits and risks related to the additional ionizing radiation received by the patient are justified. It also provides the visualization of important structures and/or conditions not recognized in other tests (Ee et al, 2014). Moreover, CBCT enables the identification of calcifications, root fractures and resorptions, anatomic variations, accidents, complications, as well as assists in post-traumatic investigation and postoperative follow-up (Desai et al, 2015; Oliveira et al, 2021). Despite these advantages, CBCT's requests related to endodontic problems remain low among professionals. To better illustrate that, in a study conducted in Southeastern Brazil among three dental radiology clinics, only $13 \%$ of 4583 requests were CBCT scans (Oliveira et al. 2021).

In the present case, the postoperative tomographic image allowed the confirmation of an altered dental morphology (Figures 4 and 5), in which tooth 23 presented two roots and two root canals. The image also collaborated to the exclusion of suspected root perforation, whose exclusion normally occurs after thorough clinical examination, guaranteeing the treatment's success. Therefore, imaging should be performed complementary to the clinical examination, allowing a successful diagnosis, treatment plan, and technique (Ee et al, 2014).

\section{Final Considerations}

Given the above, although maxillary canines mostly have one single canal, the presence of two canals should be considered. As such, endodontists shall be aware of possible anatomical variations and make use of auxiliary resources when appropriate, such as CBCT, to ensure correct diagnosis and, consequently, successful root canal treatment.

\section{Competing Interests}

The authors deny any conflicts of interest related to this study.

\section{References}

Alapati, S., Zaatar, E. I., Shyama, M., \& Al-Zuhair, N. (2006). Maxillary canine with two root canals. Medical Principles and Practice, 15(1), 74-76. https://doi.org/10.1159/000089390

Barkhordar, R. A., \& Nguyen, N. T. (1985). Maxillary canine with two roots. Journal of Endodontics, 11(5), 224-227. https://doi.org/10.1016/S00992399(85)80064-9

Bolla, N., \& Kavuri, S. R. (2011). Maxillary canine with two root canals. Journal of conservative dentistry: JCD, 14(1), 80. 10.4103/0972-0707.80726

Desai, P. D., Dutta, K., \& Sarakar, S. (2015). Multidetector computed tomography dentascan analysis of root canal morphology of maxillary canine. Indian Journal of Dental Research, 26(1), 31. 10.4103/0970-9290.156794

Ee, J., Fayad, M. I., \& Johnson, B. R. (2014). Comparison of endodontic diagnosis and treatment planning decisions using cone-beam volumetric tomography versus periapical radiography. Journal of Endodontics, 40(7), 910-916. https://doi.org/10.1016/j.joen.2014.03.002

Gopalakrishnan, A., Unnikrishna, K., Balan, A., \& Haris, P. S. (2017). Use of Cone-Beam Computed Tomography in the Diagnosis and Treatment of an Unusual Canine Abnormality. Sultan Qaboos University Medical Journal, 17(2), e238. 10.18295/squmj.2016.17.02.019

Hasna, A. A., \& Carvalho, C. A. T. (2019). Endodontic treatment of a large periapical cyst with the aid of antimicrobial photodynamic therapy-Case report. Brazilian Dental Science, 22(4), 561-568. https://doi.org/10.14295/bds.2019.v22i4.1745

Hasna, A. A., Da Silva, L. P., Pelegrini, F. C., Ferreira, C. L. R., de Oliveira, L. D., \& Carvalho, C. A. T. (2020). Effect of sodium hypochlorite solution and gel with/without passive ultrasonic irrigation on Enterococcus faecalis, Escherichia coli and their endotoxins. F1000Research, 9. 10.12688/f1000research.24721.1 
Research, Society and Development, v. 10, n. 2, e36410212599, 2021

(CC BY 4.0) | ISSN 2525-3409 | DOI: http://dx.doi.org/10.33448/rsd-v10i2.12599

Hasna, A. A., de Toledo Ungaro, D. M., de Melo, A. A. P., Yui, K. C. K., da Silva, E. G., Martinho, F. C., \& Gomes, A. P. M. (2019). Nonsurgical endodontic management of dens invaginatus: a report of two cases. F1000Research, 8. 10.12688/f1000research.21188.1

Hasna, A. A., Khoury, R. D., Toia, C. C., Gonçalves, G. B., de Andrade, F. B., Carvalho, C. A. T., ... \& Valera, M. C. (2020). In vitro evaluation of the antimicrobial effect of $\mathrm{N}$-acetylcysteine and photodynamic therapy on root canals infected with Enterococcus faecalis. Iranian Endodontic Journal, 15(4), 236245. https://doi.org/10.22037/iej.v15i4.26865

Kavitha, M., Gokul, K., Ramaprabha, B., \& Lakshmi, A. (2014). Bilateral presence of two root canals in maxillary central incisors: A rare case study. Contemporary clinical dentistry, 5(2), 282. 10.4103/0976-237X.132354

Lamba, B. (2012). Rarity in midst of routine: case report of a maxillary canine with two root canals. international journal of stomatology \& occlusion medicine, 5(1), 49-51. 10.1007/s12548-012-0037-8

Mohammed, N. M. A., Mandorah, A. O., \& Alqashqari, T. A. (2015). Maxillary canine with two root canals. Saudi Endodontic Journal, 5(2), 146. $10.4103 / 1658-5984.155456$

Muppalla, J. N. K., Kavuda, K., Punna, R., \& Vanapatla, A. (2015). Management of an Unusual Maxillary Canine: A Rare Entity. Case reports in dentistry, 2015. https://doi.org/10.1155/2015/780908

Oliveira, P. D. A. C., Franco, A., Oliveira, L. B., Lima, C. A. S., Junqueira, J. L. C., Cavalette, M. R. M. L., \& Oenning, A. C. C. (2021). Cone-beam computed tomography in Endodontics: an exploratory research of the main clinical applications. Research, Society and Development, 10(1), e42910111842e42910111842. https://doi.org/10.33448/rsd-v10i1.11842

Orguneser, A., \& Kartal, N. (1998). Three canals and two foramina in a mandibular canine. Journal of Endodontics, 24(6), 444-445. https://doi.org/10.1016/S0099-2399(98)80031-9

Plascencia, H., Cruz, Á., Palafox-Sánchez, C. A., Díaz, M., López, C., Bramante, C. M., \& Ordinola-Zapata, R. (2017). Micro-CT study of the root canal anatomy of maxillary canines. Journal of clinical and experimental dentistry, 9(10), e1230. 10.4317/jced.54235

Roy, D. K., Cohen, S., Singh, V. P., Marla, V., \& Ghimire, S. (2018). Endodontic management of mandibular canine with two roots and two canals: a rare case report. BMC research notes, 11(1), 1-4. https://doi.org/10.1186/s13104-018-3226-8

Scarparo, R. K., \& Neuvald, L. R. (2006). Avaliação dos métodos radiográfico e eletrônico para determinação do comprimento real de trabalho em endodontia-estudo in vivo. Revista da Faculdade de Odontologia-UPF, 11(2). https://doi.org/10.5335/rfo.v11i2.1112

Shin, D. R., Kim, J. M., Kim, D. S., Kim, S. Y., Abbott, P. V., \& Park, S. H. (2011). A maxillary canine with two separated root canals: a case report. Journal of Korean Academy of Conservative Dentistry, 36(5), 431-435. https://doi.org/10.5395/JKACD.2011.36.5.431

Shrivastava, N., Nikhil, V., Arora, V., \& Bhandari, M. (2013). Endodontic management of mandibular canine with two canals. Journal of the International Clinical Dental Research Organization, 5(1), 24. 10.4103/2231-0754.134133

Vertucci, F. J. (1984). Root canal anatomy of the human permanent teeth. Oral Surgery, Oral Medicine, Oral Pathology and Oral Radiology, 58(5), 589-599. https://doi.org/10.1016/0030-4220(84)90085-9

Victorino, F. R., Bernardes, R. A., Baldi, J. V., Moraes, I. G. D., Bernardinelli, N., Garcia, R. B., \& Bramante, C. M. (2009). Bilateral mandibular canines with two roots and two separate canals: case report. Brazilian Dental Journal, 20(1), 84-86. https://doi.org/10.1590/S0103-64402009000100015 